\title{
How some Seemingly Moderate Political Elections Results may Redirect a State's Historical Course, from the Top Down to the Transformation of National Growth and Socio-Cultural Development Patterns: Turkey's Political Reforms over the Last Decades as an Ideal Paradigm of Multi- Faceted National Re-Orientation
}

\author{
John Karkazis ${ }^{1}$ \\ Georgios C. Baltos ${ }^{2}$ \\ Janis Balodis ${ }^{3}$ \\ ${ }^{1}$ Prof. John Karkazis is the Dean of Business School, \\ University of the Aegean, Chios, Greece \\ ${ }^{2} P h . D(c)$ of Business School, University of the \\ Aegean, Chios, Greece \\ ${ }^{3}$ Belarusian Economic Research and Outreach Center \\ (BEROC), Minsk, Belarus
}

Doi: 10.2478/ajis-2018-0012

\section{Abstract}

This paper discusses a model for identifying and evaluating how the critical changes in the politics of a state impact its socio-economic life. Political transitions of this magnitude may stem out of elections results, but they are not limited to governmental reforms, since they further create a historical rift between the former and the latter status. They definitely initiate regime turnovers, geostrategic reorientation and shifts of geopolitical axes, but they also transform the national growth and socio-cultural development structures and features. The case study chosen refers to Turkey's political transformation over the last decades; it is considered an ideal paradigm for testing the relevant research questions due to the extent and depth of the revolutionary changes triggered by the Islamic or the so called neoottoman political parties taking over power and overthrowing the long-lasting status quo of kemalism. The consequences of the before mentioned political shift are being examined in correlation with certain statistical indicators like students' enrolment in the education system. The statistics are projected over a time series covering previous and current status. Then they are mapped via a Geographic Information System on a regional spatial context towards more comprehensive visual representation and further interpretation of the structural changes indicated.

Keywords: political transformation, Turkey, socio-economic indicators, Geographic Information System, regional mapping

\section{Introduction}

The critical changes in the politics of a state impact in general its socio-economic life. Some of them, however, signal exceptional political transitions, not just limited to governmental reforms, as long as they further create a historical rift between the former and the latter ideological characteristics underlying a national identity (see Fig. 1). They definitely initiate regime turnovers, geostrategic re-orientation and shifts of geopolitical axes, but they also transform the national 
growth and socio-cultural development structures and features (Anayasa, 2011). The case study chosen refers to Turkey's political transformation over the last decades; it is considered an ideal paradigm for testing the relevant research questions due to the extent and depth of the revolutionary changes triggered by the Islamic or the so called neo-ottoman political parties taking over power and overthrowing the long-lasting status quo of kemalism.

The consequences of the before mentioned political shift are being examined in correlation with certain statistical indicators like students' enrolment in the university education system. The statistics are projected over a time series covering previous and current status. Then they are mapped via a Geographic Information System (ArcGis 9.3.1-Datum: WGS 1984) on a regional spatial context towards more comprehensive visual representation and further interpretation of the structural changes indicated.

Consequently, this study examined the expected progress of tertiary education in the proIslamic Anatolia as a reflection of Turkey's socio-political transformation from the kemalist to the so called "neo-ottoman" ideological universe. Taken the Turkish elections wave of reforming results before and after 2000 as the dependent factor, and given the limited length of an academic paper, the independent factor prioritized and chosen was one related with the education (Erisen, 2014). The model was set up to indicate regional changes, testing the hypothetical impact of the applied neo-ottoman policies upon the semantic tertiary student's enrolment, whose quantity and quality is of significance for any proclaimed wide and deep social development (Cizre, 2008).

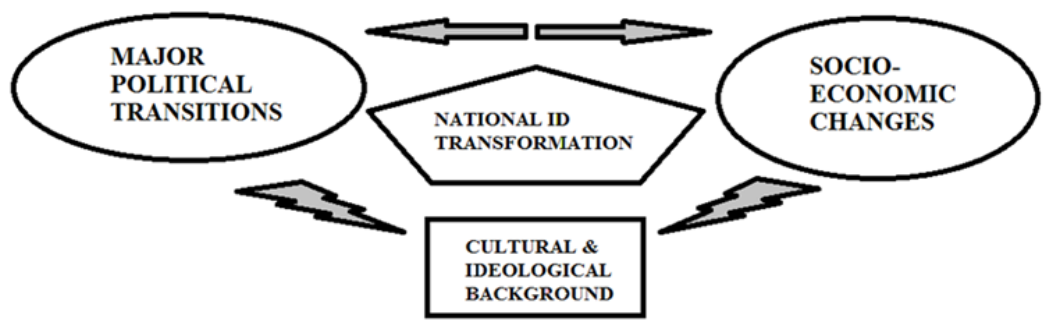

Fig. 1. The interaction between major political transitions and socio-economic changes may have such magnitude resulting in national identity transformation (Source: made by the authors).

\section{Historical Background of the Political Shift}

Turkey was established on the ruins of the Ottoman Empire. In 1923, Mustafa Kemal Ataturk, the so called "Father of the Turks" launched an ambitious campaign to create a modern country based on western social life norms if not on western values (Erickson and Hook 2013). At the crossroads of political and social evolution in Turkey, all the relevant historical descriptions and analyses of Turkey lie on the common grounds of remarkable volatility as well as dramatic cultural clashes. The Turkish state draws the attention for its diverse or even hybrid features mixing up oriental and western lifestyles, elections, coups and dictatorships, secularism and theocracy. Its geopolitical environment is of such significance that Turkish leadership have been always in the temptation of "punching above their weight". Sometimes they have succeeded (Gokhan Ulum, 2014). However, the latest decades establish new challenges related to a strategic future that is inextricably bound up with the future of immediate neighbors in the region as well as the superpowers conflicting interests (Baltos, Vidakis, Balodis, 2017). The current Turkish answer against the afore-mentioned challenges is mainly the rhetoric and the practice of a "new Turkey", which practically invoked in a context of division between two eras, the Kemalist period (the old Turkey) versus the post-Kemalist period marked by the Justice and Development Party (AKP) governance (Kocamaner, 2015).

The implementation of democracy during a state's evolution is a long and multi-faceted process. It may be at the first place reviewed and justified through the examination of using the terminology basics of a democracy: suffrage, elections, parliamentary representation, etc. (Kabir, 
2014). Theoretically, these are the foundational institutions of democracy, but more and less democratic countries use the terms and reserve the title for themselves, given that they are anyway administered by the incumbent governments which keep the first word on certifying the validity of the multi-type election results (Przeworski, 2009). At the next step of democratic maturity, the emphasis is placed on the recognition of the citizens' and parties' right to oppose governments, applying and enjoying respective freedoms. The ultimate end though is to uplevel the society along with the citizens quality of life and prospective for peace and prosperity (Senay, 2013). This is all explained in regard with the usual question following a political status or even regime change; is it, for example, the above mentioned "new Turkey" more or less democratic than the old one, is the post-kemalist era promising better days for the Turkish people?

Since the times of T. Ozal, there were significant efforts to bring the peripheral Anatolian populations in a course of progress and prosperity after they had been neglected by the so called "deep kemalist state" for decades. T. Ozal questioned the republican practices that were leaving the less developed eastern rural areas in the shadow of the western more advanced urban ones (Karkazis, Baltos, Vidakis, 2017). The human and material resources hidden there where progressively activated in the form of Islamic capital deployed by local businesses, religious communities and Middle Eastern funds (White, 2011). These entrepreneurs, dramatically called "Anatolian Tigers", were trained to survive with no state support, therefore, when they were somehow facilitated towards their operations, dynamically excelled and flourished (Öztürk, 2011). Despite the severe political obstacles, the Islamic parties met all the way from T. Ozal to R.T. Erdogan, the fight against the republican status quo was victorious; the latter continued the former's initiatives, won multiple elections up to the point that the country lately has been strategically transformed with apparently difficult or no way back (Metin, Toktas, 2003).

\section{Methodology}

From a general point of view, the political theories determine a threefold framework of analytical layers; the first one is the global (systemic/external), where the prior role belongs to the international factors influencing the country-states decision making (alliances, economic dependence, energy resources scarcity, etc.). The next layer is the states' governments (internal), in other words the political regime as it is defined by the contemporary leadership, while the last one is the individual citizen's social development at the bottom of the political powers pyramid (Jackson, Sorensen, 2006). It is underlined that the states are the protagonists of internal and external relations, since acting as sovereign political units they take full responsibility for their stance and actions. However, the consequences result in the daily life of the citizens, who may suffer or prosper because of the statesmen policies and practices (Karaosmanoglu, 2011).

All these three layers simultaneously impact long running strategies, but their contribution weights depend on the dynamically changing circumstances. Extending further the aforementioned approach, and towards interpreting decision making, this paper examines the projection of major changes against a long-lasting and ideologically deep-rooted political status quo, like the so called centennial kemalist status quo in Turkey, towards the citizens' quality of life and the behaviors they deploy as a reaction to the political transition activities surrounding them (Phillips, 2017). The interaction of the political change with citizens' lifestyle choices is being further examined in time and space dynamic context (Friedman, 2016). The time series include a part of the previous as well as a part of the new political order, while the effects of the transition are being mapped, using visual, comprehensive and credible, representation tools provided by a well-recognized geographic information system (Öztürk, 2011).

The case study explores the impact of endogenous political forces on characteristic socioeconomic institutions before, during, and after an Islamic party took over the state control and governance in the Turkish Republic. After the mild military intervention of 1997, against the swift ruling of Turkey by N. Erbakan's Islamic party, electoral masses concentrated on R.T. Erdogan's attempt to recover the political Islamic return to power, as it really happened (Guiler, 2016). The released political rigor launched the shift of other societal pillars, thus economic and social reforms recommended by political Islam attitudes were soon implemented. The elections in Turkey are 
presented as the pivotal reference point of a state in transformation (see the specific Elections timeline in Fig. 2).

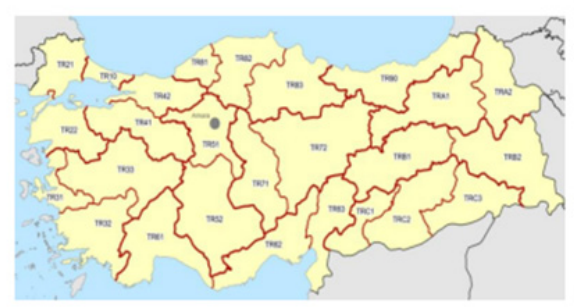

1) The NUTS 2 levels in Turkey;

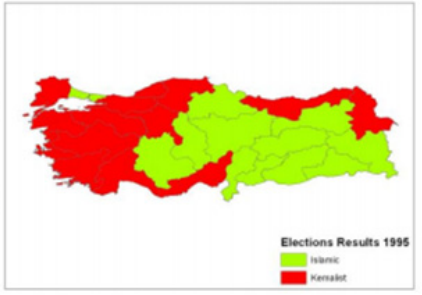

2) Turkey's 13th general election in 1995;

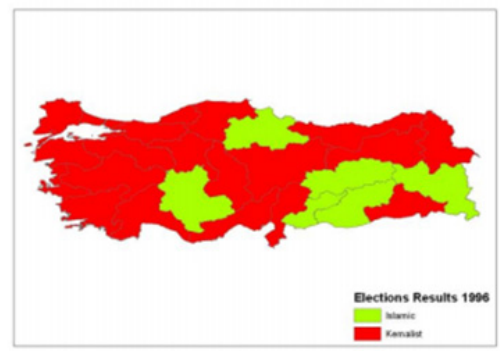

3) Turkey's 14th general election in 1996;

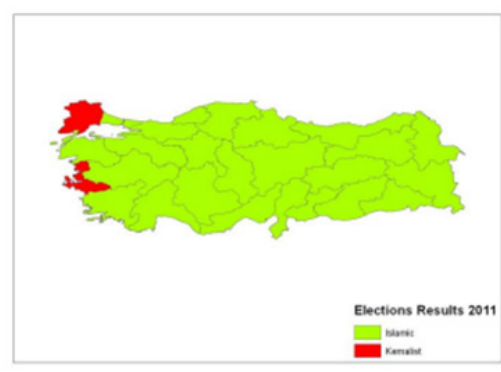

5) Turkey's 17th general election of 2011;

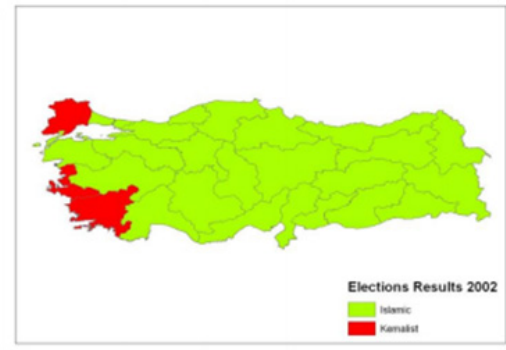

4) Turkey's 15th general election in 2002;

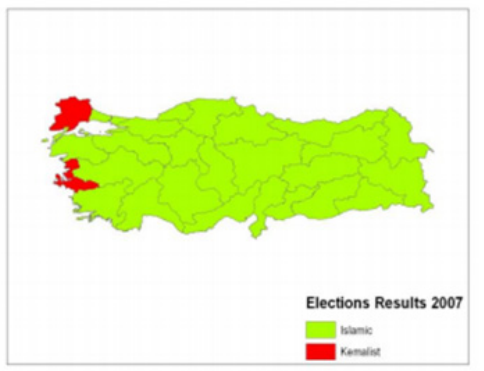

6) Turkey's 16th general election of 2007;

Fig. 2. The elections timeline for the reference period. Regional Elections results presented on the NUTS 2 territorial unit basis (EUROSTAT Statistics Explained, 2017). Red (or dark grey for b/w images) and green (or light grey) colors reflect kemalist and pro-Islamic majority votes respectively.

The mechanism of elections is an expression of pro-Islamic public opinion political feelings that progressively transform the old-time secularist fortresses, some of the difficult-to-enter, highly elitist and segmented pro-kemalist institutions like the universities. It is still to investigate the content of the curricula in the universities that opened, after 2002, their gates to multiple students not having access before. The religious programs themselves surely increased the size of the tertiary enrolment, but no matter the "religious-friendly" orientation of many university sectors, the specialized, theoretical and practical, prospective provided are populating the educational successes, whose practice confirms our hypothesis that the political shock resulted in multi-layered societal revolutions. In this context, the rationale for conducting this case study research on a state influenced by deep ideological earthquakes proved to be fully justified. 


\section{Statistical Analysis}

Subject data taken from the Organization for Economic Co-operation and Development (OECD) (OECD, 2017). Regions editions, United Nations Development Programme (UNDP, 2016) (Human Development Index) and Turkish Statistical Institute were helpful for understanding both individual and collective behaviors of residents (Turkish Statistical Institute, 2017), providing statistical material at the sub-national level, graphs and maps available for comparisons. It was then possible to identify the ways that elections regional results, correlated with social like the educational figures and characteristics, increased our research capacity to diagnose local development, as well as criteria and requisites applied towards mobilizing resources for daily life changes at each region level. Measuring education levels, concluded on narrative snapshots of how life was being lived, and consequently how can be improved at each separate region registered as an OECD area. This pilot experiment showcases the contribution of a country's regions to social progress via wider participation into the educational system, drawing on specific comparable data and certain time trends across regions (Oguz, Pinarcioglu, 2006). The education is an ideal indicator to highlight the rise and/or fall of regional disparities, underscoring institutional changes and common characteristics among developing regions (OECD, 2011).

Mixed linear models were used in order to find out if there were any significant changes over time and if these changes differentiate according to the regional political status. Thus, the regression equation included terms for political status and time. Adjusted regression coefficients $(\beta)$ with standard errors (SE) were calculated from the results of the mixed models. These models are remarkably useful in exercises where repeated measurements are performed on the same statistical units (longitudinal study). Given their advantage to deal with missing values, mixed effects models are often preferred (Ciddi, 2009). In the current study, student enrolments of tertiary education were the repeated units and dependent variables that were measured annually from 1995 to 2005. Interactions of political status and time were tested in order to investigate if the effect of the political status on dependent variables was different or consistent over time. Log transformations were used in all dependent variables. All $p$ values stated are two-tailed (see Fig. 3). Statistical significance was set at $p<0.05$ and analyses were managed using STATA statistical software (version 9.0).
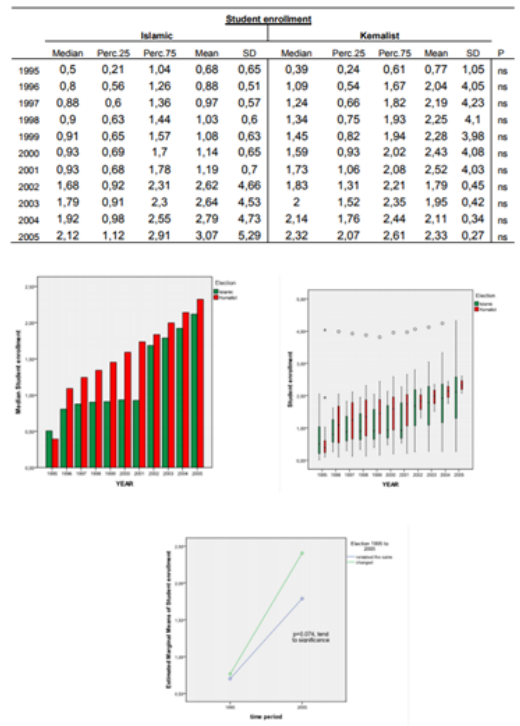

Fig. 3. Correlation results of Elections (1995-2011) - Social Factor (Student Enrolments in Tertiary Education, 1996-2005). 


\section{Geographic Information System Analysis}

On the side of geographic information systems (GIS), the extended but also credible use of them in population studies needs careful attention in regard with the methods applied. Since several studies have provided limited and selective information that hampers the assessment over the validity of spatial data, this paper statistically validated all relevant data feeding GIS maps through respective regression analyses. This way revealed highly reliable geographic data. Using such cross-checked approach combining both geographic info processing and statistical verification, the methods and the model developed created an accurate spatial database possibly available for further investigation of other socio-economic indicators. Additionally, the current results depict the feasibility of developing in a retrospective way a reliable GIS for a large set of data applied over multiple regions and sequential time periods of a case study country like Turkey. Last but not least, this paper introduces in a visually aided way some solutions facing the challenges in retrospectively creating a GIS, whose quantitative completeness supports afterwards the qualitative interpretation of overall social changes feeding back the political changes in a virtuous or malicious cycle of history production (Robinson et al. 2010). The figure below (Fig. 4) represents the tertiary student's enrolment situation, year after year, before R.T. Erdogan wins the elections of 2002.

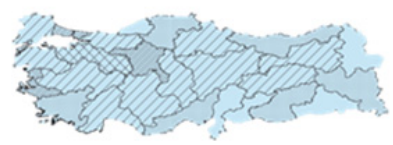

1) Student enrollment in 1996

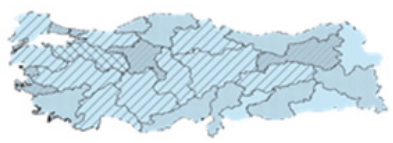

3) Student enrollment in 1998

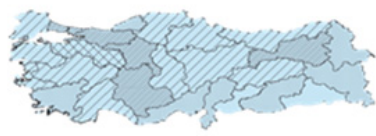

5) Student enrollment in 2000

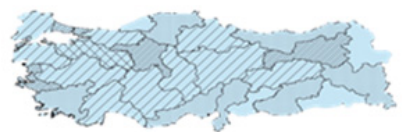

2) Student enrollment in 1997

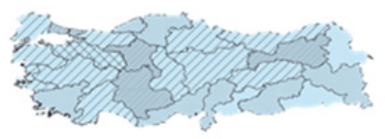

4) Student enrollment in 1999

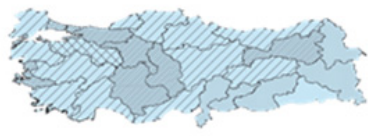

6) Student enrollment in 2001

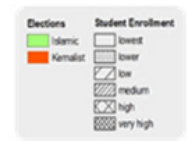

Fig. 4. GIS mapping of the tertiary students enrolment situation, year after year, before R.T. Erdogan wins the elections of 2002.

The choice of an indicator related to the education does not anyway need justification due to the given importance of this institution for any society's development. Especially for Turkey though, 
progress in education was declared as a strategic priority of the AKP government over its first decade of service. The Turkey's Millennium Development Goals (MDGs) Report that was published in 2005 explicitly stated commitments taken and goals set towards achieving the educational MDGs (Cagaptay, 2014), along with the activities launched and results accomplished since 2000. Although the frontline of this national challenge seems to be "providing primary education to the entire country" the millennium goal covers the whole range of open access and education upgrades (Tugal, 2016).

Just for the records, at that time period approximately one million children of primary school age were not going to school. The respective gender gap was $7 \%$ against girls, while the majority of these children were living in the mountainous eastern and southeastern regions. The MDG itself was framed by campaigns known as "Off to School, Girls!" ("Haydi Kizlar Okula!") which were of the first tasks taken over by the respective Ministry under the auspices of UNICEF in 2003, aiming to contain the enrolment gaps between eastern and western provinces (Somuncu, 2006). In this context, the figure below (Fig. 5) represents the tertiary students enrolment situation, year after year, after R.T. Erdogan wins the elections of 2002.

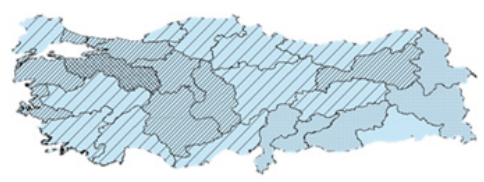

1) Student enrollment in 2002

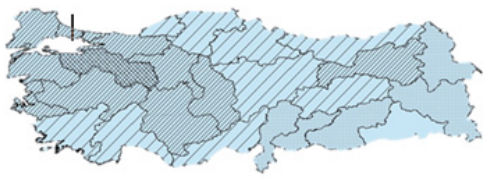

3) Student enrollment in 2004

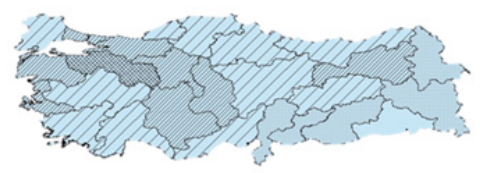

2) Student enrollement in 2003

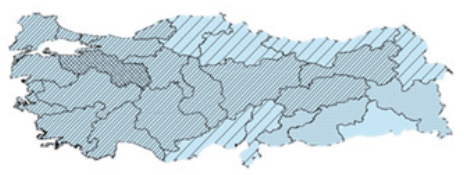

4) Student enrollement in 2005

Fig. 5. GIS mapping of the tertiary students' enrolment situation, year after year, after R.T. Erdogan wins the elections of 2002.

\section{Correlation (Elections - Student Enrolment)}

The AKP government, at the first decade of its reforming performance achieved sustainable growth and wide job creation, rooted also in the reforms in the education and consequently at the labor market, where education and training initiatives are applied and materialized, driving to economic gains and developing opportunities. The growth in discussion, as we mentioned before was driven by the industrial boost of Anatolian regions, although the western regions remained competitive (Celebioglu, Dall'erba, 2010). In the process of tertiary education improvements, the occupational orientation and participation started rising dynamically anew; for instance, many new jobs had been quickly redirected to high level information technologies. 


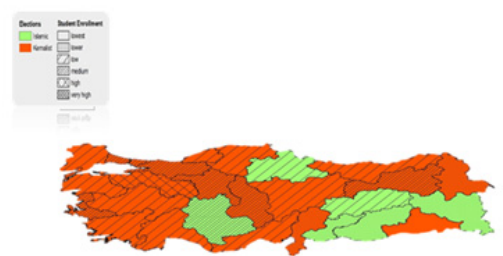

1) The elections in 1996 and student enrollment in 2001

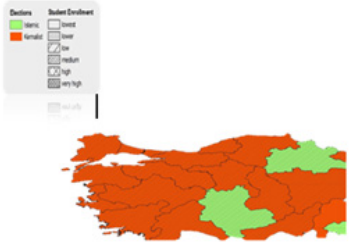

3) The elections in 1996 and student enrollment in 2001 in the Western and Central Turkey's provinces

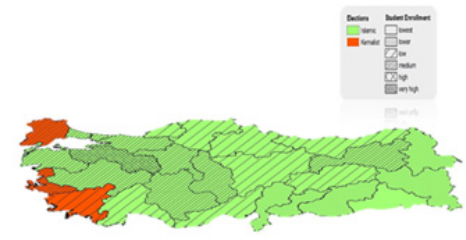

2) The elections in 2002 and student enrollment in 2004

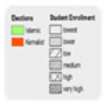

4) The elections in 2002 and student enrollment in 2004 in the Western and Central Turkey's provinces

Fig. 6. The combined results of mixed-model regression analysis for Elections-Tertiary Students Enrolment.

The combined results of mixed-model regression analysis for tertiary student enrolment are presented above (see Fig. 6). Student enrolment increased during the following the Election milestone of 2002 years, but the overall interaction effect of time with political status was not significant, indicating that the increase of student enrolment was similar for both kemalist and postkemalist eras. However, in case of Kemalist voters' regions the student enrolment was consistently lower (Seufert, 2014). On the opposite, in the regions with pro-Islamic voters' majorities the student enrolment was consistently higher. For instance, two years after AKP took the political power, the province of East Marmara (see Fig. 7) presented dramatic increase, in regard with the examined social indicator, of $25 \%$ compared to the almost flat rate referring to the last five years of the kemalist period.

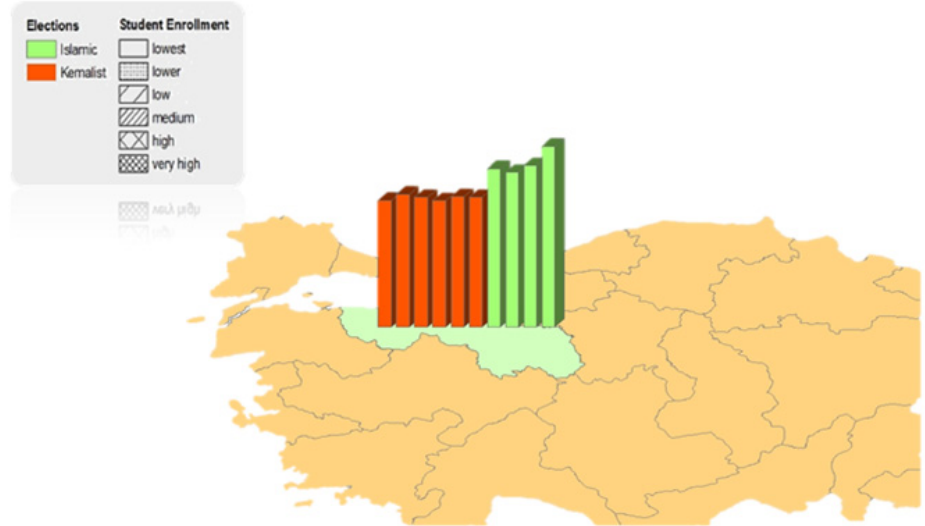

Fig. 7. The dynamics of tertiary student enrolment in the East Marmara (NUTS 2: TR 41) region over the years from 1996 to 2005. Kemalist status in red (or dark grey for b/w images)-colored and post-kemalist in green (or light grey)-colored bars. 


\section{Conclusions and Further Research Fields}

Summing up, UN, OECD, Turkish Statistics Center data and EU criteria assisted in analysing, as a dependent variable, state educational development along with the independent variables, Turkey's political elections continuum on the verge from $20^{\text {th }}$ to $21^{\text {st }}$ century (Gallagher, Mitchel, 2005). The major conclusions are that the nature of this particular political transformation from kemalists to neo-ottomans explains Turkey's improved status in the higher educational system of competitive regions; that equation may apparently apply in a wider range of evolutions, demonstrating how the early phase of "Erdoganism", as an era of reforming ideologico-political drivers, improved Turkey's institutions not only towards accelerated educational reform, but also in terms of wider citizens participation and business growth, although at the expense of secularism, according to the political Islam prerogatives. The fact was that the educational reforms in discussion continued with a broad opening of the tertiary education to the lower social classes in previously less developed regions of Anatolia, curtailing illiterature, increasing social benefits for traditional outliers excluded from the privileges of the so called once upon a time Kemalist elites (Nadolski, 2000).

As it is demonstrated by the Working Papers annexed to the 2012 OECD Economic Survey of Turkey, sustaining growth proved possible only by being supported by brave educational structural reforms (Brezzi, 2012). In a few words the prerequisite of education reforms, from elementary to tertiary level and specialized vocational training unleashes productivity, as well as administration effectiveness and efficiency. As we may witness today that the global economic crisis burst out in 2008 and beyond, it is remarkable that the Turkish economy managed to run through that rough worldwide difficulties with minor losses (Yavuz, 2010). The current economic demise stemmed out of adversary following up political circumstances, but in reference to the 2000-2012 period, the alternative growth scenarios played by the Turkish leadership illustrated how progress on education deliver improvements in terms of average living standards.

\section{References}

Anayasa, Y. (2011). Expectations of the Turkish Society from the New Constitution. Istanbul: Wise Men Center for Strategic Studies, (Online) Available: https://www.academia.edu/2491836/Expectations_of_the _Turkish_Society_from_the_New_Constitution?auto=download (Accessed on 21 December, 2017)

Baltos, G, C, Vidakis, I, G \& Balodis, J. (2017). Turkey's Ambitions to Emerge as a Regional Power: Example or Counter-Example for Potential Aspiring Competitors. Academic Journal of Interdisciplinary Studies, 6, 33 46.

Brezzi, M. (2012). Territorial Grids of OECD Member Countries. Paris: Directorate of Public Governance and Territoral Development.

Cagaptay, S. (2014). The Rise of Turkey: The Twenty-First Century's First Muslim Power. Nebraska:Potomac Books, Inc, Nebraska Press.

Celebioglu, F \& Dall'erba, S. (2010). Spatial disparities across the regions of Turkey: an exploratory spatial data analysis, Ann Reg Sci, 45, 379-400.

Ciddi S. (2009). Kemalism in Turkish Politics: The Republican People's Party, Secularism and Nationalism. Routledge: Abingdon-on-Thames.

Cizre, Ü. (2008). Secular and Islamic Politics in Turkey: The Making of the Justice and Development Party, Routledge, Abingdon-on-Thames.

Erickson, E.J., and A. Hook. (2013). Mustafa Kemal Atatürk. London: Bloomsbury Publishing.

Erisen,C. (2014). Political Psychology of Turkish Political Behavior. Routledge: Abingdon-on-Thames.

EUROSTAT Statistics Explained. (2017). EU imports of energy products - recent. (Online) Available: developmentshttp://epp.eurostat.ec.europa.eu/statistics_explained/index.php/Eurostat_regional_yearbook . (Accessed on 13 November, 2017)

Friedman, G. (2016). Beyond the Turkish Coup, Geopolitical Futures, 10, pp. 1 -5.

Gallagher, M \& Mitchel, P. (2005). The Politics of Electoral Systems, Oxford University Press, Oxford.

Gokhan Ulum, O. (2014). Recep Tayyip Erdogan: The Brave Heart: The Father of New Turkey, Maryland: America Star Books.

Guiler, K, (2016). Towards Erdogan and the East: Conspiracies and public perception in post-coup. Istanbul: Turkey Contemporary Turkish Politics, Project on Middle East Political Science.

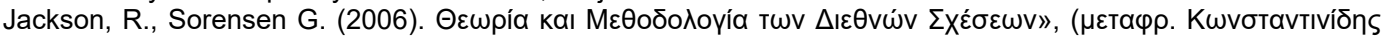

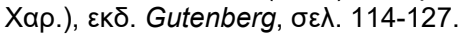


Kabir, T. (2014). The Reckoning of Pluralism - Political Belonging and The Demands of History of Turkey. Stanford: Stanford University Press.

Karaosmanoglu, A. (2011). Armed Forces and Democracy. Istanbul: Wise Men Center for Strategic Studies.

Karkazis, J., Baltos, G., Vidakis, I. (2017). The current Turkish geopolitics as a product of personal leadership aspirations, challenging traditional methods of risk management and power measurement. Foreign affairs: the Hellenic edition, 47, 94-115.

Kocamaner, H. (2015). How New Is Erdoğan's “New Turkey”?, Middle East Brief, 91, 1 - 9.

Metin, H and Toktas, S. (2003). Islam, Modernity, and Democracy in Contemporary Turkey: The Case of Recep Tayyip Erdogan. The Muslim World, 2, 157-185.

Nadolski, D, J. 2000. The etatist Turkish Republic and its political and socio-economic performance from 19801999: A developing state impacted by international organizations and interdependence. 9999155 Ph.D. Kansas: University of Missouri - Kansas City.

OECD. (2011). OECD Regions at a Glance 2011. Paris: Organisation for Economic Co-operation and Development/Organisation de Cooperation et de Developpement Economiques.

OECD. (2017). OECD Regions at a Glance. (Online) Available: http://www.oecd-ilibrary.org/urban-rural-andregional-development/oecd-regions-at-a-glance_19990057;jsessionid=1knjt7wsr5jd0.epsilon (Accessed on 21 December, 2017)

Oguz, I and Pinarcioglu, M. (2006). Geographies of a silent transition: a geographically weighted regression approach to regional fertility differences in Turkey, European Journal of Population, No,, 390 - 399.

Öztürk, I. (2011). Political economy of Erdoğan's success story in Turkey. London: Al Jazeera Centre for Studies.

Phillips, D, L. (2017). An Uncertain Ally: Turkey under Erdogan's Dictatorship.Routledge: Abingdon-on-Thames.

Przeworski, A. (2009). The Mechanics of Regime Instability in Latin America, in: Journal of Politics in Latin America. Journal of Politics in Latin America, 1, 1, 5-36.

Robinson, J, C., Sharon B. Wyatt, S, B, Hickson, D, Gwinn, D, Faruque, F, Sims, M, Sarpong, D and Herman A. Taylor. (2010). "Methods for Retrospective Geocoding in Population Studies: The Jackson Heart Study. Journal of Urban Health, 87,136-50.

Senay, B. (2013). Beyond Turkey's Borders - Long - Distance Kemalism, State Politics and the Turkish Diaspora, London: I. B. Tauris.

Seufert, G. (2014). Erdoğan's "New Turkey" Restoring the Authoritarian State in the Name of Democracy. Berlin: German Institute for International and Security Affairs. SWP Comments.

Somuncu, M. (2006). Achieving Universal Primary Education in Mountains: Turkey's Education Campaign for Girls: "Off to School, Girls!" ("Haydi Kizlar Okula!"). Mountain Research and Development, 1,20-23.

Tugal, C. (2016). The Fall of the Turkish Model: How the Arab Uprisings Brought Down Islamic Liberalism, New York: Verso Books.

Turkish Statistical Institute. (2017). Income, Living, Consumption and Poverty. (Online) Available http://www.turkstat.gov.tr/Start.do;jsessionid=3ggrP2sXjmLF2MQmRLnLqJWInnL2LB31QH9BvJNXQW7r C2Q7xLIB!-1998769340 (Accessed on 21 December, 2017)

UNDP. (2016). Human Development Statistics. (Online) Available http://hdrstats.undp.org/en/tables/ (Accessed on 21 December, 2017)

White, J. (2011), Islamist Mobilization in Turkey: A Study in Vernacular Politics, University of Washington Press, Washington.

Yavuz, E, A (2010). Wage Inequality in Turkey: Decomposition by Statistical Regions, 1980-2001. Review of Urban \& Regional Development Studies, 1, 55 - 72. 